\title{
Learning Content and Process for Academically Talented Students
}

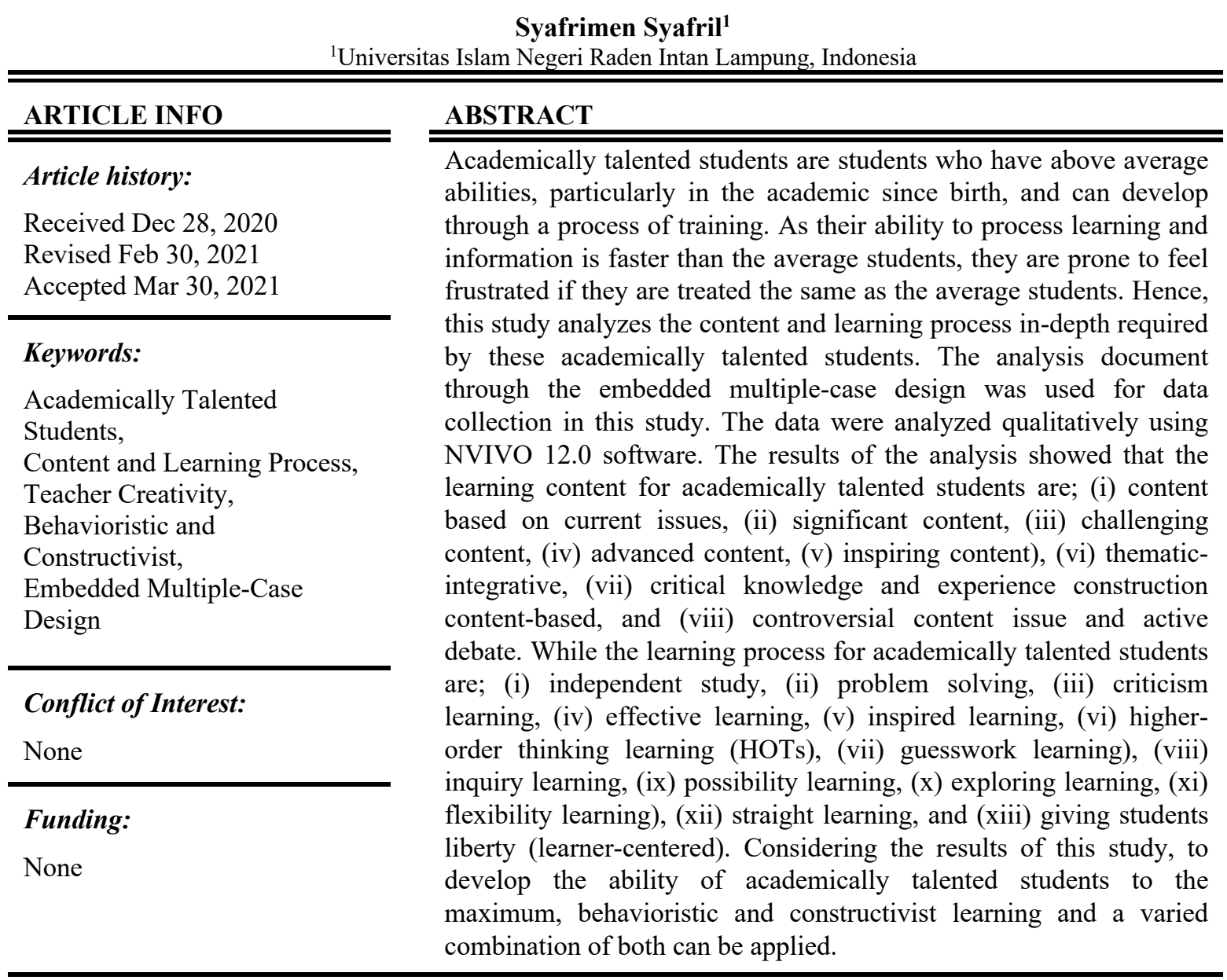

Corresponding Author: Syafrimen Syafril, Universitas Islam Negeri Raden Intan Lampung, Jl. Letkol H. Endro Suratmin, Sukarame, Bandar Lampung, Indonesia. Tel. +6281374576227. E-mail: syafrimen@radenintan.ac.id.

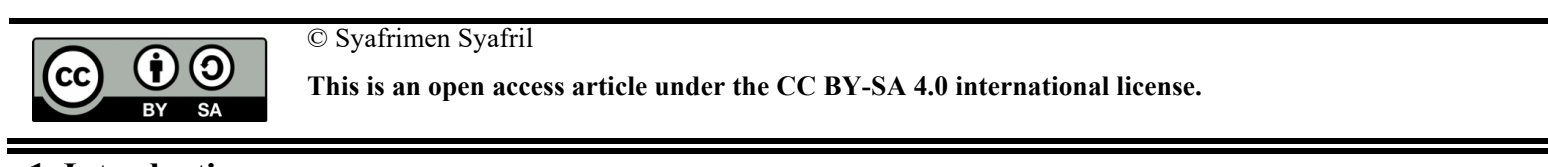

1. Introduction

Academically talented students are defined as students who possessed intellectual abilities above average and can perform outstandingly, have courage, achievement, creativity, innovation, and motivation, as well as special abilities in academics (Ambrose \& Machek, 2015; Chang \& Qin, 2017; S. Lee et al., 2018; McCoach et al., 2004; Mills, 1993; Renzulli, 1978; Syafril et al., 2020; Vogelaar et al., 2019; Yusof et al., 2020; Zhbanova et al., al., 2013). Characterized by the high value obtained and more active in learning (K. M. Lee et al., 2017; Pollet \& Schnell, 2017; Villatte et al., 2011). Academically talented students have potential abilities that they were born with and can develop optimally through the environment and training (Taslim \& Jabar, 2019; Wahab, 2005). Academically talented students own a positive academic self-concept (Dixon et al., 2001; Vogelaar \& Resing, 2018). Based on these various views, academically talented students are 
identified as students who have superior abilities or whose intelligence levels are above the average regular students and can be developed through constant training.

Academically talented students have characteristics: possess more positive self-concept, perfectionists, have abundant enthusiasm and physical energy, general intellectual abilities, creative or productive thinking, leadership abilities, psychomotor abilities, cognitive abilities, have a high sense of curiosity, keen on challenges, more responsive and easy to memorize, have extraordinary abilities in reading, intelligent, flexible, sensitive, extraordinary reasoning abilities, have efficient memory span, have the ability to identify and discard irrelevant information, apply approaches to solving problems, expressive, idealistic, and superior analytical thinking skills (McCoach \& Siegle, 2003) (Dixon et al., 2001; Maksić \& Iwasaki, 2009; Pfeiffer \& Stocking, 2000) (Fox, 1981; Harkness, 1988; Lupart, 1991; Majida \& Alias, 2010; Syafril et al., 2020) (AlHadabi, 2010; Eilam \& Vidergor, 2011; Jones \& Day, 1996; Mulhern, 197 8; Yusof et al., 2020) (Neihart, 2008). Talented students have a more rapid ability to learn and process information, work at a higher level in subject matter, and focus on conceptual content higher than their peers (Van Tassel-Baska et al., 1992). They are moderately shown in Figure 1.1 below.

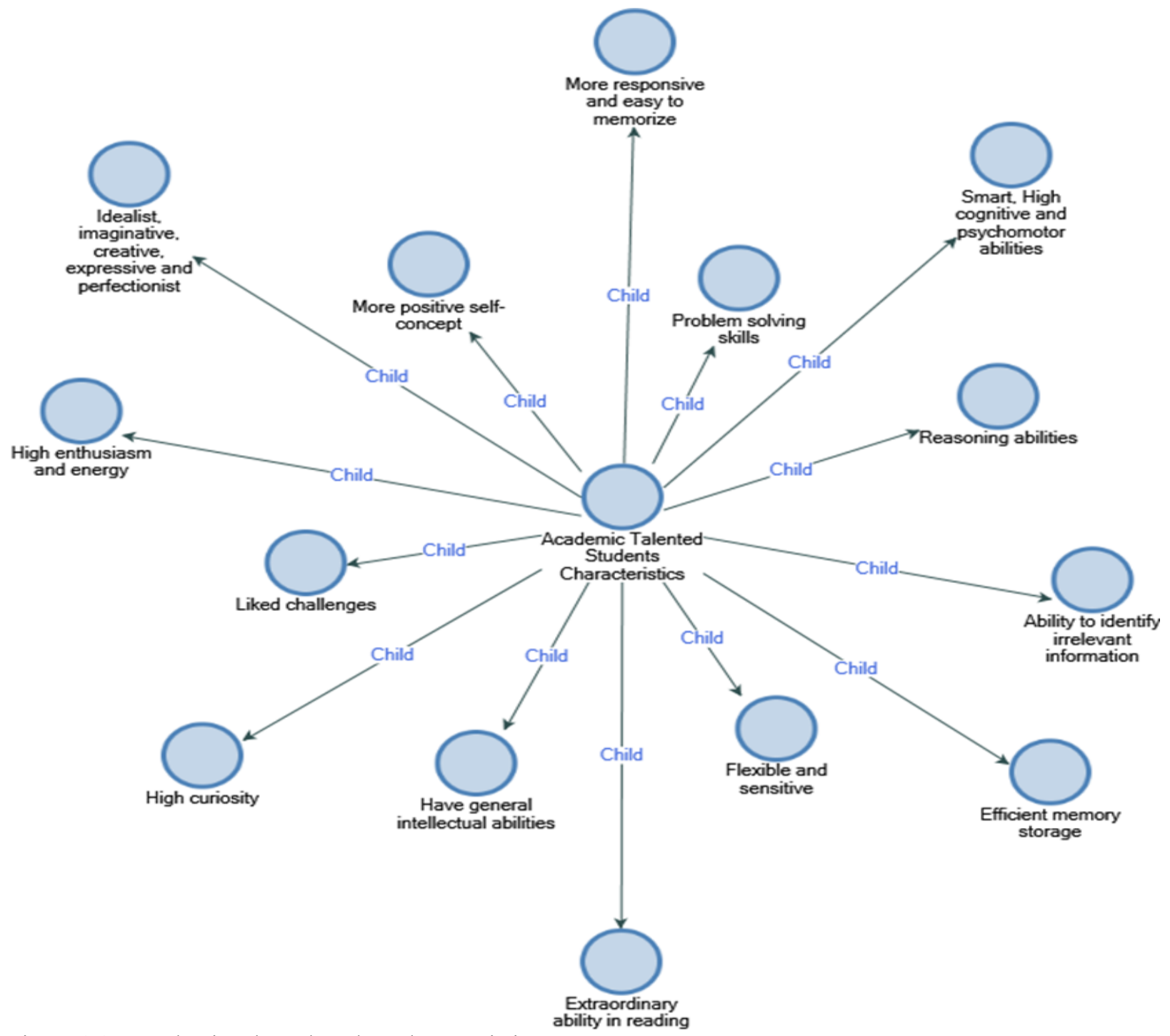

Figure 1.1. Academic talented student characteristics

Very often, the lack of quality material or content conveyed to these academically talented students and ineffective learning environment, thus did not meet students' expectations (Özarslan \& Çetin, 2018), inadequate learning about concepts that consider content related to mathematics and physics (Grouws et al., 1996). Academically talented students are sometimes seen to underperform in learning due to learning style and lack of interest in learning (Lapointe et al., 2005; Stewart, 1981). Academically talented students are often delayed in order for other children to complete their work (Martin, 2002). Academically talented 
children are bored, saturated, and exasperated when treated the same as other children, where their needs are not met, due to their ability to process learning and information faster (Benson, 2002). There is a need for variation in the learning experience and the need for different features between academically talented students and students in general. Academically talented students possessed distinct characteristics and requirements that make learning effective and efficient (Waldrop, 1990).

Research on content and learning processes has been conducted by previous studies, including project-based learning processes to support academically talented students interested in learning materials and developing their enthusiasm, interest, and attitude towards learning (Özarslan \& Çetin, 2018). Teachers are also required to produce activities that reflect achievement in the school environment, including in (academic) subjects, achievements in music, fine arts, and sports activities (non-academic achievements), and in interpersonal and leadership activities (Chan, 2008). However, academically talented students need challenging programs as well as providing learning processes that can challenge students' weaknesses in problem -solving skills and independent skills (Beckely, 1998), critical thinking skills (Del Giorno, 1977), discussion, and active learning (Peterson \& Lorimer, 2012; Sisk, 1972), culture-based learning, learning content that transforms theory into practice (McHatton et al., 2010), and learning content that visualizes theory (Gordon \& Poze, 1980). Academically talented students require programs that are academically and creatively challenging (Perez, 1980). It is important to consider each academically talented student's needs in selecting the appropriate curriculum in the learning process (Tyler - Wood et al., 2000). Therefore, research related to the content and learning process for academically talented students is still minimal and is obligated to answer various questions as described earlier.

\section{Method}

This study used a qualitative approach with case study research types (Chesebro \& Borisoff, 2007; Creswell, 2014; Mason, 2014; Yin, 2017). Case studies were used as a comprehensive explanation related to aspects of a person, group, organization, a program, or a community situation that were studied to be developed and analyzed in depth. The design of this study is an embedded multiple-case design, which involves more than one unit of analysis (Baxter \& Jack, 2008; Scholz \& Tietje, 2012). Data were collected through analytical documents (theory, scientific articles, management documents, and teacher-prepared learning process documents) (Bastani et al., 2018; Bowen, 2009; Esterberg, 2014; Fossey et al., 2002; Moen \& Middelthon, 2015). Data were analyzed thematically through data reduction, data display, and conclusion drawing and verification (James, 2013). All data analysis techniques were performed with the assistance of NVIVO 12.0 software to facilitate in analyzing and organizing data to produce themes or essential points to find out the appropriate content and learning process for academically talented students.

\section{Results and Discussion}

Academically talented students possess learning differences from other students. Hence, there is a requirement for content and learning processes for academically talented students that is essential to be developed by teachers to focus on those students' academic talents. Generally speaking, learning for academically talented students is oriented towards Behavioristic and Constructivistic learning, and a combination of the two is varied. Based on the analysis document conducted, the learning content for academically talented students is shown in Figure 3.1 below. 


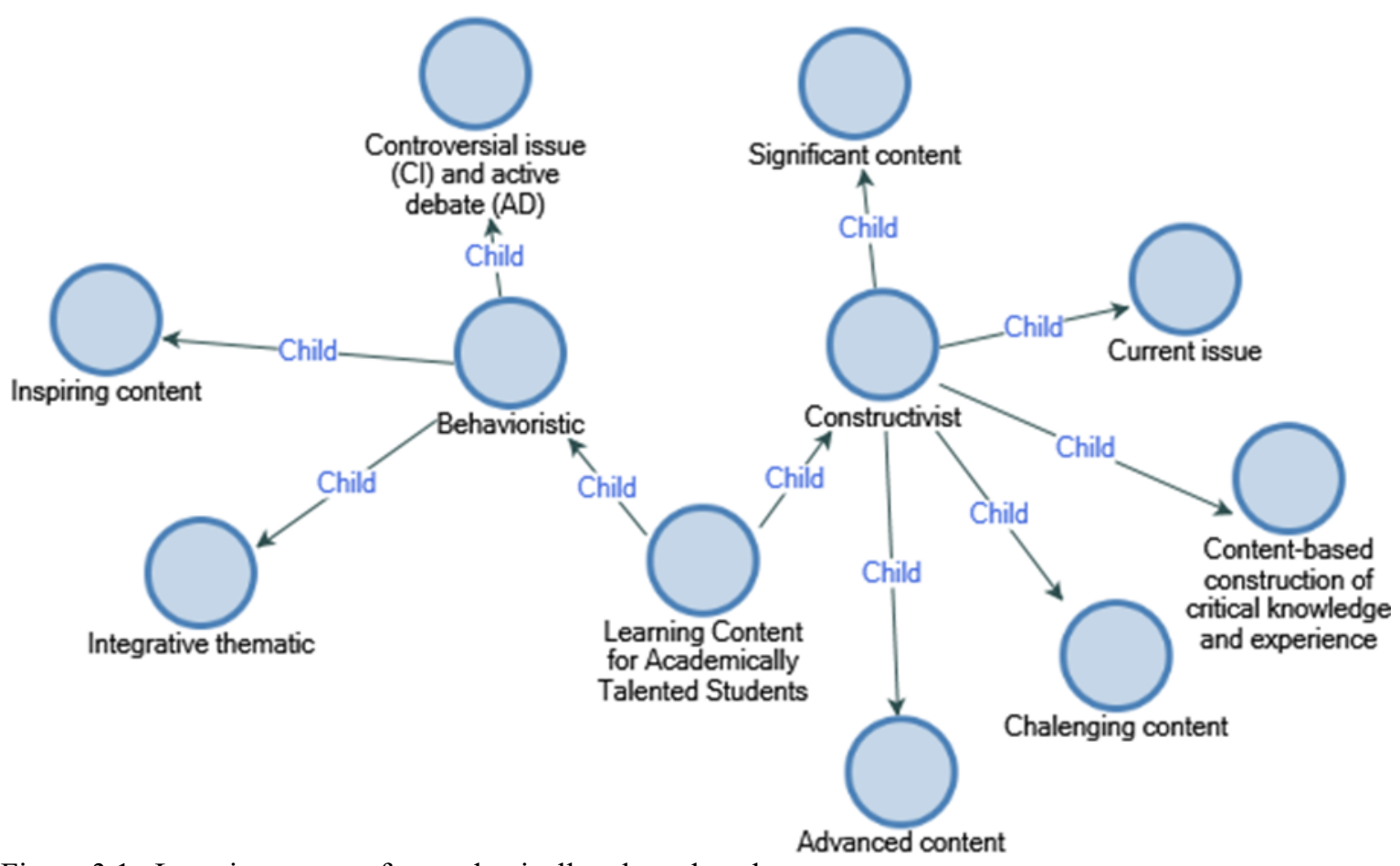

Figure 3.1. Learning content for academically talented student

An in-depth understanding of each of these learning content is described below: (i) Current issue-based content (Gross \& Smith, 2019; Ruban \& Reis, 2005; VanTassel-Baska, 2005). Content that comprises current issues by reducing introductory material and material that students have already know in evading boredom and speeding up the learning process. (ii) Significant content: refers to a variety of extra learning or tasks used to elaborate on academically talented students' abilities to expand students' understanding of the learning material or content conveyed. (iii) Challenging content: refers to efforts to challenge talented students to learn more complexly and obtain more information and may not be grasped by regular average students. (iv) Innovative content (advanced content): refers to efforts to present content that is not covered in the school curriculum (J. J. Gallagher, 1994). (v) Inspiring content: to reinforce solid conceptual reasoning to help academically talented students learn (Rogers, 2007). (vi) thematic-integrative content, i.e., not only the material of a lesson. Academically talented students are adept at learning new content or facts and should be encouraged to pursue learning at their own pace (Watters \& Diezmann, 2003). (vii) Content-based construction of critical knowledge and experience (Chowdhury, 2016) is learning content that encourages students to construct knowledge independently through critical discourse with their own experiences, fellow students, and teachers. (viii) Moreover, CI and AD (Controversial Issue and Active Debate) content is learning content that takes controversial issues and learning content that encourages students to debate in the learning process actively (Aini et al., 2019; J. Gallagher et al. al., 1997).

Furthermore, the results of the analysis related to the learning process for academically talented students as shown in Figure 3.2 below: 


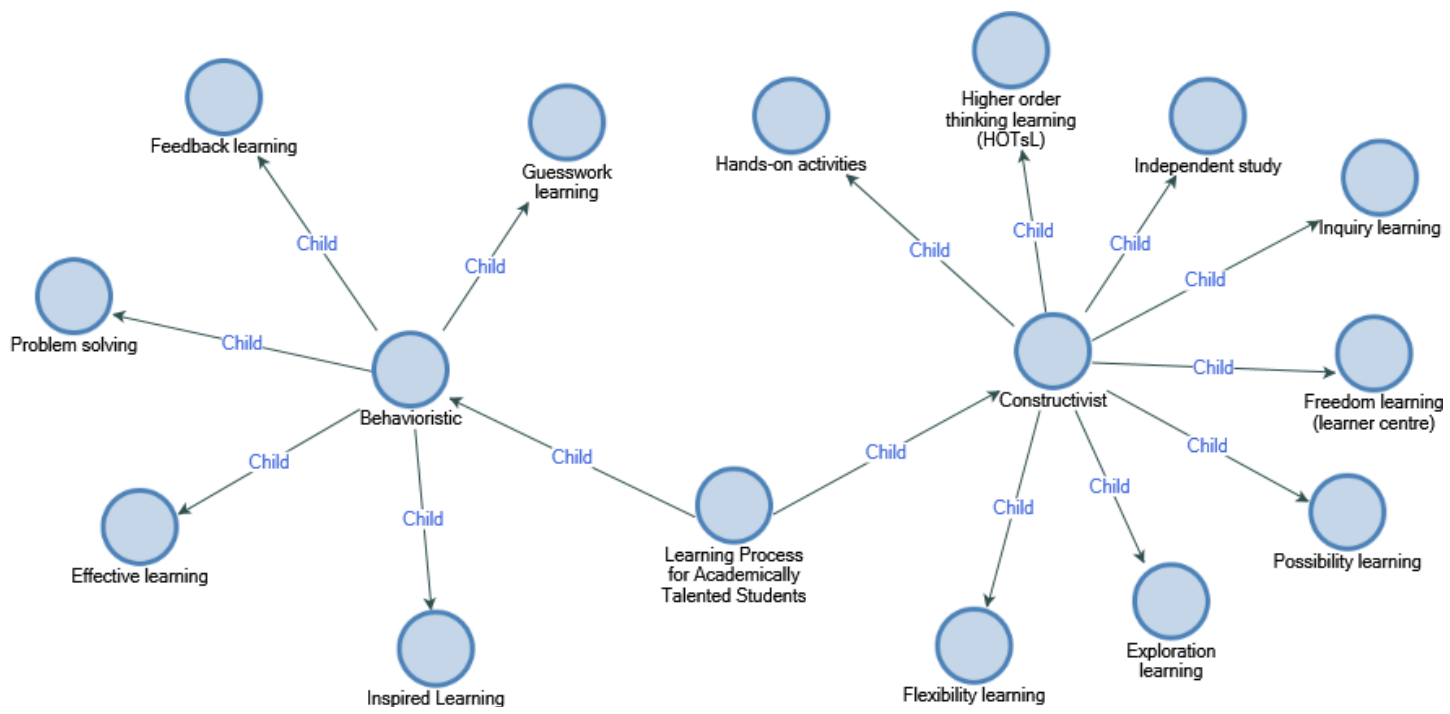

Figure 3.2. The learning process for academically talented student

Comprehensive understanding of each of the learning processes for academically talented students is described below: (i) Independent study, academically talented students prefer independent learning, projects, and independent learning materials than regular average students. Independent learning impacts learning motivation (inner motivation and external motivation) and ultimately affects the academic achievement obtained by students (Berman et al., 2012; Rogers, 2007). Individual strategies (independence) positively affect learning, evidenced by increased cognitive growth (Betts \& Neihart, 1986). (ii) Problem-solving, academically talented students execute a planned process to acquire knowledge through problem-solving provided in a study. (iii) Feedback (criticism learning), critical interaction between students with students, and students with teachers in the learning process. (iv) Develop practical learning skills by providing activities that lead to specific experiences through training to achieve maximum results. (v) Inspired learning is a learning process that inspires students' creativity for maximum ability development through rewards and positive rewards (Kim et al., 2013). (vi) Higher-order thinking learning (HOTs), academically talented students have abilities above their peers so that the learning process builds high-level thinking creativity. (vii) Encourage the willingness to speculate (guesswork learning), (viii) Inquiry learning, and learn by cultivating the courage to inquire. (ix) Possibility learning by increasing the willingness to take risks. (x) Exploratory learning, learning with research and investigation. (xi) Flexibility learning increase flexibility to develop students' interest (xii) Learning through direct activities (straight learning), students' involvement with learning that triggers students' curiosity. With the aim of students to become more interested in the learning process. (xiii) Learning that grants liberty to students (learner-centered) is a learning process that provides the broadest possible autonomy to students to explore knowledge through various sources. Such a learning process may precede other peers (Calero et al., 2011; Cropley \& McLeod, 1986; Park \& Oliver, 2009; Sak, 2004; Scot et al., 2008; Scott et al., 2016; Swartz, 1993).

\section{Conclusion}

Intellectual ability above peers since birth, able to develop through the influence of the environment and continuous training, is a characteristic of academically talented students. Content and the learning process should be able to develop the student's abilities to the core. Behavioristic and Constructivistic Learning and a combination of the two can be used variably, as shown by the results of this study. For that reason, it takes a high level of creativity by teachers to realize the content and the learning process to meet the learning requirements of academically talented students.

\section{References}

Aini, N. R., Syafril, S., Netriwati, N., Pahrudin, A., Rahayu, T., \& Puspasari, V. (2019). Problem-Based Learning for Critical Thinking Skills in Mathematics. Journal of Physics: Conference Series, 1155(1). https://doi.org/10.1088/1742-6596/1155/1/012026 
Al-Hadabi, A. S. D. (2010). Yemeni primary education teachers' perception of gifted students' characteristics and the methods for identifying these characteristics. Procedia - Social and Behavioral Sciences, 7(C), 480-487. https://doi.org/10.1016/j.sbspro.2010.10.065

Ambrose, L., \& Machek, G. R. (2015). Identifying Creatively Gifted Students: Necessity of a Multi-Method Approach. Contemporary School Psychology, 19(3), 121-127. https://doi.org/10.1007/s40688-014$\underline{0020-\mathrm{Z}}$

Bastani, P., Samadbeik, M., Dinarvand, R., Kashefian-Naeeini, S., \& Vatankhah, S. (2018). Qualitative analysis of national documents on health care services and pharmaceuticals' purchasing challenges: Evidence from Iran. BMC Health Services Research, 18(1), 1-9. https://doi.org/10.1186/s12913$\underline{018-3261-0}$

Baxter, P., \& Jack, S. (2008). Qualitative Case Study methodology: Study Design and Implementation for Novice Researchers. The Qualitative Report, 13(4), 544-559. https://doi.org/10.1039/c6dt02264b

Beckely, D. (1998). Gifted and Learning Disabled: Twice-Exceptional Students. NRC/GT Spring Newsletter. University of Connecticut, 7. http://www.gifted.uconn.edu/nrcgt/newsletter/spring98/sprng984.html

Benson, L. (2002). Serving gifted students through inclusion: A teacher's perspective. Roeper Review, 24(3), 126-127. https://doi.org/10.1080/02783190209554151

Berman, K. M., Schultz, R. A., \& Weber, C. L. (2012). A Lack of Awareness and Emphasis in Preservice Teacher Training. Gifted Child Today, 35(1), 18-26. https://doi.org/10.1177/1076217511428307

Betts, G. T., \& Neihart, M. (1986). Implementing Self-Directed Learning Models for the Gifted and Talented. Gifted Child Quarterly, 30(4), 174-177.

Bowen, G. A. (2009). Document analysis as a qualitative research method. Qualitative Research Journal, 9(2), 27-40. https://doi.org/10.3316/QRJ0902027

Calero, M. D., Belen, G. M. M., \& Robles, M. A. (2011). Learning Potential in high IQ children: The contribution of dynamic assessment to the identification of gifted children. Learning and Individual Differences, 21(2), 176-181. https://doi.org/10.1016/j.lindif.2010.11.025

Chan, D. W. (2008). Goal orientations and achievement among gifted Chinese students in Hong Kong. High Ability Studies, 19(1), 37-51. https://doi.org/10.1080/13598130801980307

Chang, T. F., \& Qin, D. B. (2017). Relations Between Academic Adjustment and Parental Psychological Control of Academically Gifted Chinese American and European American Students. Child Indicators Research, 10(3), 715-734. https://doi.org/10.1007/s12187-016-9403-1

Chesebro, J. W., \& Borisoff, D. J. (2007). What Makes Qualitative Research Qualitative? Qualitative Research Reports in Communication, 8(1), 3-14. https://doi.org/10.1080/17459430701617846

Chowdhury, M. A. (2016). Gifted education in science and chemistry: Perspectives and insights into teaching, pedagogies, assessments, and psychosocial skills development. Journal for the Education of Gifted Young Scientists, 4(1), 53-66. https://doi.org/10.17478/JEGYS.2018116581

Creswell, J. W. (2014). A Concise Introduction to Mixed Methods Research. SAGE Publication.

Cropley, A., \& McLeod, J. (1986). Preparing Teachers of the Gifted. International Review of Education, 32(2), 125-136.

Del Giorno, B. J. (1977). Retal as a model for developing critical and divergent thing in gifted and talented students of science. Gifted Child Quarterly, 21(1), 58-69. https://doi.org/10.1177/001698627702100110

Dixon, F. A., Cross, T. L., \& Adams, C. M. (2001). Psychological characteristics of academically gifted students in a residential setting: A cluster analysis. Psychology in the Schools, 38(5), 433-445. https://doi.org/10.1002/pits.1032

Eilam, B., \& Vidergor, H. E. (2011). Gifted Israeli students' perceptions of teachers' desired characteristics: A case of cultural orientation. Roeper Review, 33(2), 86-96. https://doi.org/10.1080/02783193.2011.554156

Esterberg, K. G. (2014). Qualitative Methods in Social Research. Mc Graw Hill.

Fossey, E., Harvey, C., Mcdermott, F., \& Davidson, L. (2002). Understanding and Evaluating Qualitative Research. Australian and New Zealand Journal of Psychiatry, 36(6), 717-732. 
Fox, L. H. (1981). Identification of the academically gifted. American Psychologist, 36(10), 1103-1111. https://doi.org/10.1037/0003-066X.36.10.1103

Gallagher, J., Harradine, C. C., \& Coleman, M. R. (1997). Challenge or boredom? Gifted students' views on their schooling. Roeper Review, 19(3), 132-136. https://doi.org/10.1080/02783199709553808

Gallagher, J. J. (1994). Current and Historical Thinking on Education for Gifted and Talented Students. National Excellence: A Case for Developing America's Talent., 83-107.

Gordon, W. J. J., \& Poze, T. (1980). SES Synectics and Gifted Education Today. Gifted Child Quarterly, 24(4), 147-151. https://doi.org/10.1177/001698628002400402

Gross, M. U. M., \& Smith, S. R. (2019). Put Them Together and See How They Learn! Ability Grouping and Acceleration Effects on the Self-Esteem of Academically Gifted High School Students. Springer International Handbooks of Education, 1-26. https://doi.org/10.1007/978-981-13-3021-6_17-1

Grouws, D. A., Howald, C. L., \& Colangelo, N. (1996). Student Conceptions of Mathematics: A Comparison of Mathematically Talented Students and Typical High School Algebra Students. Paper Presented at the American Educational Research Association, New York. http://eric.ed.gov/?id=ED395783

Harkness, J. (1988). College studies for the gifted: An academic approach for meeting the needs of gifted, talented, and creative students. Roeper Review, 11(2), 77-79. https://doi.org/10.1080/02783198809553170

James, S. (2013). Participant Observation. Rinehart \& Winston Publish.

Jones, K., \& Day, J. D. (1996). Cognitive similarities between academically and socially gifted students. Roeper Review, 18(4), 270-273. https://doi.org/10.1080/02783199609553757

Kim, K. H., Kaufman, J. C., John, B., \& Sriraman, B. (2013). Creatively Gifted Students are not like Other Gifted Students. In Creatively Gifted Students are not like Other Gifted Students. https://doi.org/10.1007/978-94-6209-149-8

Lapointe, J. M., Legault, F., \& Batiste, S. J. (2005). Teacher interpersonal behavior and adolescents' motivation in mathematics: A comparison of learning disabled, average, and talented students. International Journal of Educational Research, 43(1-2), 39-54. https://doi.org/10.1016/j.ijer.2006.03.005

Lee, K. M., Jones, M. K., \& Day, S. X. (2017). The impact of academic competency teasing and self-concept on academic and psychological outcomes among gifted high school students. Learning and Individual Differences, 56, 151-158. https://doi.org/10.1016/j.lindif.2016.10.020

Lee, S., Matthews, M., Shin, J., \& Kim, M. (2018). Academically gifted adolescents' social purpose. High Ability Studies, 00(00), 1-26. https://doi.org/10.1080/13598139.2018.1533452

Lupart, J. L. (1991). Issues in identifying gifted students: How Renzulli's model stacks up. Roeper Review, 14(2), 53-58. https://doi.org/10.1080/02783199109553386

Majida, R. A., \& Alias, A. (2010). Consequences of risk factors in the development of gifted children. Procedia - Social and Behavioral Sciences, 7(C), 63-69. https://doi.org/10.1016/j.sbspro.2010.10.010

Maksić, S., \& Iwasaki, K. (2009). The perfectionism of Academically Gifted Primary School Students: The Case of Japan. Gifted and Talented International, 24(2), 51-60. https://doi.org/10.1080/15332276.2009.11673529

Martin, C. (2002). Serving gifted students through inclusion: A parent's perspective. Roeper Review, 24(3), 127. https://doi.org/10.1080/02783190209554152

Mason, J. (2014). Qualitative Researching (2nd ed., p. 59). Sage Publication.

McCoach, D. B., Kehle, T. J., Bray, M. A., \& Siegle, D. (2004). The Identification of Gifted Students with Learning Disabilities: Challenges, Controversies, and Promising Practices. Students with Both Gifts and Learning Disabilities, 31-47. https://doi.org/10.1007/978-1-4419-9116-4 3

McCoach, D. B., \& Siegle, D. (2003). The structure and function of academic self-concept in gifted and general education students. Roeper Review, 25(2), 61-65. https://doi.org/10.1080/02783190309554200

McHatton, P. A., Boyer, N. R., Shaunessy, E., Terry, P. M., \& Farmer, J. L. (2010). Principals' Perceptions of Preparation and Practice in Gifted and Special Education Content: Are We Doing Enough? 
Journal of Research on Leadership Education, 5(1), 1-22. https://doi.org/10.1177/194277511000500101

Mills, C. J. (1993). Personality, learning style and cognitive style profiles of mathematically talented students. European Journal of High Ability, 4(1), 70-85. https://doi.org/10.1080/0937445930040108

Moen, K., \& Middelthon, A. L. (2015). Qualitative Research Methods. In Research in Medical and Biological Sciences: From Planning and Preparation to Grant Application and Publication. Elsevier Ltd. https://doi.org/10.1016/B978-0-12-799943-2.00010-0

Mulhern, J. D. (1978). The gifted child in the regular classroom. Roeper Review, 1(1), 3-6. https://doi.org/10.1080/02783197809552340

Neihart, M. (2008). Identifying and Providing Services to Twice-Exceptional Children. Handbook of Giftedness in Children, 115-137. https://doi.org/10.1007/978-0-387-74401-8 7

Özarslan, M., \& Çetin, G. (2018). Effects of biology project studies on gifted and talented students' motivation toward learning biology. Gifted Education International, 34(3), 205-221. https://doi.org/10.1177/0261429417754203

Park, S., \& Oliver, J. S. (2009). The translation of teachers' understanding of gifted students into instructional strategies for teaching science. Journal of Science Teacher Education, 20(4), 333-351. https://doi.org/10.1007/s10972-009-9138-7

Perez, G. S. (1980). Perceptions of the young, gifted child. Roeper Review, 3(2), 9-11. https://doi.org/10.1080/02783198009552508

Peterson, J. S., \& Lorimer, M. R. (2012). Small-Group Affective Curriculum for Gifted Students: A Longitudinal Study of Teacher-Facilitators. Roeper Review, 34(3), 158-169. https://doi.org/10.1080/02783193.2012.686423

Pfeiffer, S. I., \& Stocking, V. B. (2000). Vulnerabilities of Academically Gifted Students. Special Services in the Schools, 16(1-2), 83-93. https://doi.org/10.1300/J008v16n01

Pollet, E., \& Schnell, T. (2017). Brilliant: But What For? Meaning and Subjective Well-Being in the Lives of Intellectually Gifted and Academically High-Achieving Adults. Journal of Happiness Studies, 18(5), 1459-1484. https://doi.org/10.1007/s10902-016-9783-4

Renzulli, J. S. (1978). What Makes Giftedness? Reexamining a Definition. Phi Delta Kappan, 60(3), 180.

Rogers, K. B. (2007). Lessons learned about educating the gifted and talented: A synthesis of the research on educational practice. Gifted Child Quarterly, 51(4), 382-396. https://doi.org/10.1177/0016986207306324

Ruban, L. M., \& Reis, S. M. (2005). Identification and assessment of gifted students with learning disabilities. Theory into Practice, 44(2), 115-124. https://doi.org/10.1207/s15430421tip4402_6

Sak, U. (2004). About Creativity, Giftedness, and Teaching the Creatively Gifted in the Classroom. Roeper Review, 26(4), 216-222. https://doi.org/10.1080/02783190409554272

Scholz, R., \& Tietje, O. (2012). Embedded Case Study Methods. In Sage Publication. https://doi.org/10.4135/9781412984027

Scot, T. P., Callahan, C. M., \& Urquhart, J. (2008). Paint-by-number teachers and cookie-cutter students: The unintended effects of high-stakes testing on the education of gifted students. Roeper Review, 31(1), 40-52. https://doi.org/10.1080/02783190802527364

Scott, S., Scott, D. E., \& Longmire, L. (2016). Leading Assessment for Gifted and Talented Students: The Pursuit of Mediocrity of Excellence? Leadership of Assessment, Inclusion, and Learning, 243-272. https://doi.org/10.1007/978-3-319-23347-5

Sisk, D. (1972). Relationship between self concept and creativity: Theory into practice. Gifted Child Quarterly, 16(3), 229-234. https://doi.org/10.1177/001698627201600305

Stewart, E. D. (1981). Learning Styles among Gifted/Talented Students: Instructional Technique Preferences. Exceptional Children, 48(2), 134-138. https://doi.org/10.1177/001440298104800206

Swartz, C. W. (1993). Writing strategy instruction with gifted students: Effects of goals and feedback on selfefficacy and skills. Roeper Review, 15(4), 225-230. https://doi.org/10.1080/02783199309553512 
Syafril, S., Yaumas, N. E., Ishak, N. M., Yusof, R., Jaafar, A., Yunus, M. M., \& Sugiharta, I. (2020). Characteristics and educational needs of gifted young scientists: A focus group study. Journal for the Education of Gifted Young Scientists, 8(2), 947-954. https://doi.org/10.17478/JEGYS.691713

Taslim, P. L., \& Jabar, C. S. A. (2019). Evaluation of Acceleration Program Termination for Gifted Children Learning Needs. International Conference on Special and Inclusive Education, 296, 114-119. https://doi.org/10.2991/icsie-18.2019.22

Tyler-Wood, T. L., Mortenson, M., Putney, D., \& Cass, M. A. (2000). An effective mathematics and science curriculum option for secondary gifted education. Roeper Review, 22(4), 266-269. https://doi.org/10.1080/02783190009554050

Van Tassel-Baska, J., Landrum, M. S., \& Peterson, K. (1992). Cooperative learning and gifted students. Journal of Behavioral Education, 2(4), 405-414. https://doi.org/10.1007/BF00952357

VanTassel-Baska, J. (2005). Gifted programs and services: What are the nonnegotiables? Theory into Practice, 44(2), 90-97. https://doi.org/10.1207/s15430421tip4402 3

Villatte, A., Hugon, M., \& De Léonardis, M. (2011). Forms of self-concept in gifted high school students enrolled in heterogeneous classes. European Journal of Psychology of Education, 26(3), 373-392. https://doi.org/10.1007/s10212-011-0055-8

Vogelaar, B., \& Resing, W. C. M. (2018). Changes over time and transfer of analogy-problem solving of gifted and non-gifted children in a dynamic testing setting. Educational Psychology, 38(7), 898-914. https://doi.org/10.1080/01443410.2017.1409886

Vogelaar, B., Resing, W. C. M., Stad, F. E., \& Sweijen, S. W. (2019). Is planning related to dynamic testing outcomes? Investigating the potential for learning of gifted and average-ability children. Acta Psychologica, 196(February), 87-95. https://doi.org/10.1016/j.actpsy.2019.04.004

Wahab, R. (2005). Peranan Orang Tua dan Pendidik Dalam Mengoptimalkan Potensi Anak Berbakat Akademik. Seminar Keberbakatan, 14.

Waldrop, P. B. (1990). A structure for affective education for young, gifted children. Early Child Development and Care, 63(1), 119-129. https://doi.org/10.1080/0300443900630115

Watters, J. J., \& Diezmann, C. M. (2003). The gifted student in science: Fulfilling potential. Australian Science Teachers Journal, 49(3), 46-53.

Yin, R. K. (2017). Case Study Research and Applications: Design and Methods. In SAGE: Journal of Psychoeducational Assessment.

Yusof, R., Mokhtar, M., Ain Sulaiman, S. N., Syafril, S., \& Mohtar, M. (2020). Consistency between personality career interest with sciences field among gifted and talented students. Journal for the Education of Gifted Young Scientists, 8(3), 1147-1161. https://doi.org/10.17478/JEGYS.667323

Zhbanova, K. S., Rule, A. C., \& Stichter, M. K. (2013). Identification of Gifted African American Primary Grade Students through Leadership, Creativity, and Academic Performance in Curriculum Material Making and Peer-Teaching: A Case Study. Early Childhood Education Journal, 43(2), 143-156. https://doi.org/10.1007/s10643-013-0628-z. 